SOCIAL POLICY AND CITIZENSHIP 


\title{
SOCIAL POLICY \\ AND CITIZENSHIP
}

\author{
Julia Parker
}

Lecturer in the Department of Social and

Administrative Studies, University of Oxford

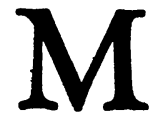




\section{(C) Julia Parker 1975}

Softcover reprint of the hardcover 1st edition 1975

All rights reserved. No part of this publication may be reproduced or transmitted, in any form or by any means, without permission.

First published 1975 by

THE MACMILLAN PRESS LTD

London and Basingstoke

Associated companies in New York Dublin

Melbourne Johannesburg and Madras

SBN 333180933 (hard cover)

333 I 8094 I (paper cover)

ISBN 978-0-333-18094-5 ISBN 978-1-349-15583-5 (eBook)

DOI $10.1007 / 97^{-1-349-155^{8}-5}$

This book is sold subject to the standard conditions of the Net Book Agreement.

The paperback edition of this book is sold subject to the condition that it shall not, by way of trade or otherwise, be lent, re-sold, hired out, or otherwise circulated without the publisher's prior consent in any form of binding or cover other than that in which it is published and without a similar condition including this condition being imposed on the subsequent purchaser. 


\section{Contents}

List of Tables vi

Introduction vii

Part I Social Policy and Social Structure I

I Models of Welfare 3

2 Kinship and Welfare $\quad 17$

3 Stratification and Welfare $\quad 29$

Part II British Social Services

4 The Distribution of Income 57

5 The Distribution of Health $7 \mathrm{r}$

6 The Distribution of Education 92

7 The Distribution of Housing 106

8 The Distribution of Welfare I25

Part II The Development of Social Policy 143

9 Citizenship I45

Io Policy Implementation $\quad$ I 8

$\begin{array}{ll}\text { Conclusions } & 169\end{array}$

$\begin{array}{ll}\text { Appendix } A & 174\end{array}$

$\begin{array}{ll}\text { Index } & 178\end{array}$ 


\section{Tables}

3.I International comparisons: G.N.P. per head; real private consumption per head; expenditure on social security; infantmortality rates and proportion of doctors to population

3.2 Per cent change in original income resulting from all taxes and benefits in 1964 and 1969 for selected household types, United Kingdom

3.3 Increases in disposable incomes between 1963 and 1969 ( 1963 Index = 100), United Kingdom

4.I Employees in organisations with pension schemes and those covered for pensions, 1971 , United Kingdom (millions)

S.I Standardised mortality ratios for men and women, 1930-2, 1949-53, and 1959-63 by social class, England and Wales

5.2 Standardised mortality ratio for men by social class and cause of death, 1959-63, England and Wales

5.3 Male standardised mortality ratio by region and class, 1959$6_{3}$, England and Wales

6.I Pupil teacher ratios: regional analysis, January 1971 , England and Wales

6.2 Proportion of pupils remaining at school until age 16 and 18 by region, maintained schools (excluding special schools) only, 1950, 1961, 1971, England and Wales (percentages)

6.3 Percentage of 13 -year-old pupils in schools and streams of various types by area, 1968 and 1971 , England and Wales

6.4 Destination of school-leavers by type of school attended, r 970-r, England and Wales (per cent of all leavers)

6.5 Proportion of all school-leavers going on to some form of full time further education, by region, 1970-1, England and Wales (percentages)

7.1 Unfit dwellings by region, 1971, England and Wales

7.2 Dwellings without exclusive use of basic amenities, I971, England and Wales

7.3 Dwellings by age, tenure and condition, 1971, England and Wales

7.4 Lack of basic amenities by tenure, 1971, England and Wales (percentages) 


\section{Introduction}

There are many ways of writing about social policy and administration but two kinds of approach have been and are particularly favoured. On the one hand the subject may be treated historically, a perspective which has many dangers. All too often it has meant a recital of successive pieces of social legislation directed to particular problems with the implicit assumption of steady progress towards a more humane society from which poverty has been abolished. Thus we learn about feudalism, where a rigid social hierarchy provided some measure of security for the poor in return for their services, of the Elizabethan statutes which tried to tackle problems of economic and demographic change by setting the unemployed to work, punishing vagrants and supporting the sick and helpless, of the New Poor Law of I834 which attempted to destroy pauperism by the repressive policies of less eligibility and deterrence, and finally of the welfare state, denoting a humane, enlightened and egalitarian society where poverty has virtually ceased to exist. This happy evolutionary process has, of course, been challenged by sceptics, particularly over the last twenty years, who refuse to admit the disappearance of the most acute material poverty as a measure of social progress, who emphasise the scandal of any degree of poverty in a rich society and who point to the gross inequalities in living standards and opportunities that persist in advanced industrial countries. There is, of course, a very different kind of historical enquiry, which attempts to identify the circumstances, interests and values influencing the development of welfare legislation, and which is vitally important in any comprehensive study of social policy.

The second kind of approach eschews the historical perspective and concentrates on the objectives, structure, responsibilities and administrative procedures of the various organisations, both statutory and voluntary, which are concerned with welfare. At its best this kind of study supplies the essential factual basis for analysing the aims and principles of social provision, for evaluating its consequences and detecting its problems. It is the stuff of which theories, if not dreams, are made. At its worst, however, it becomes a minutely detailed description, with- 
out any historical, analytical or theoretical reference, of the legislation which makes up the welfare state and of the way in which that legislation is implemented. This kind of information is necessary for social workers and administrators, but it is not in itself a proper object of attention in the academic study of social policy. It calls to mind the stern warning which decorates the walls of Manchester's Central Reference Library: 'Where is the wisdom that is lost in understanding, where is the understanding that is lost in knowledge, where is the knowledge that is lost in information?'

The purpose of this book is neither to trace the development of welfare legislation nor to describe in comprehensive detail the present arrangements. The study of social policy is here conceived as an examination of the way in which a range of goods and services - income, health, education - which are highly significant for personal well-being, are socially distributed, and in particular of the part government policies play in that distribution. The book has three aims: to set out a theoretical approach to the academic study of social policy, to examine British arrangements in terms of that approach, and to point to the problems involved in developing a system which attempts to relate services to need.

In the first instance, and as a step towards a theoretical frame of reference, I outline three possible welfare models, each embodying a distinctive approach to questions of social distribution based on different principles which have varying implications for government policy. Special attention is paid to the third or socialist model in which need, linked to the idea of citizenship, is the most important criterion for distribution.

The concepts of need, demand and supply are used throughout the book with reference to welfare and the social services. All three words have the vagueness and convenience of common speech : all three require an anticipatory remark of clarification and warning here. Supply and demand, as economists use these terms, have a familiar and precise meaning in the context of market exchange. In a perfect market supply is determined by owners' or manufacturers' decisions according to their judgements of relative value, and demand is similarly determined by the judgements of consumers, the two being adjusted to one another by price. The conditions of a free market do not, however, obtain with regard to welfare goods and services. On the supply side there is the state, which may monopolise or dominate provision and which operates through a bureaucracy backed by law or established administrative practice. The state, moreover, is not bound by direct considerations of marginal profitability. It may be required by law to provide a service or impose a standard, though it may at the same time have regard to economic costs, cost effectiveness or cost-benefit calculations, and it 
may be in competition with private market supplies as, for example, in health or education. Moreover, still on the supply side, welfare is also a function of kinship, neighbourly and community activity generated by neither law nor profit but by custom, usage, kindliness or social obligation - all forces whose sway over human behaviour may change with changing social conditions. In other words, both markets and bureaucracies operate in the context of particular social structures. The quantity and quality of the welfare they supply will consequently vary.

In a similar way, social and economic conditions constrain the quality and quantity of what is demanded. Familes may be more or less scattered and more or less reliable in supporting their members. Legal entitlement may be more or less known, more or less stigmatised, and appeals for assistance more or less encouraged by state or private agencies. Income distribution may be more or less unequal and so give rise to fluctuating statutory entitlement, for example to supplementary benefits or to unemployment pay.

The concept of need has to be analysed before relating it to either demand or supply. It may be given a physiological meaning as ' $\mathrm{X}$ ' calories per day for the maintenance of physical efficiency. Or it may have a quasi-objective social meaning in relation to the established norms of, say, housing, clothing or diet of a given country. It may also have a subjective meaning as a rich man may be poor or at least 'relatively deprived' in his own estimation and with regard to particular reference groups. Thus a wide range of meanings exists. For the purposes of this book the term is used in a restricted sense to denote two relevant considerations. First, it refers to a criterion which may be used in a non-market situation for political decisions about supply and for the legal or administrative recognition of demand. Thus, in health, the doctor is licensed to assess medical need and to distribute his 'doctor's orders' accordingly. His authority is constrained, in the case of the National Health Service, by established powers and preferences which determine what resources shall be available for particular medical purposes (for example surgery as against geriatric care) and ultimately by the total resources allocated to the Health Service from the public purse. But distribution in that context of the objective variations in people's circumstances with respect

Second, the word 'need' has a meaning distinct from 'demand' in the context of the objective variations in people's circumstances with respect to standards of health, housing, social security, child care and individual well-being. Industrialisation, modernisation, urbanisation, egalitarian values - all represent changing conditions of human need in the sense in which the term is used below. Where neither family nor community nor market meet the social demands which are generated and recognised by a society, varying pressures develop for different kinds of public intervention. Professions arise, among them the social-work profession, with 


\section{INTRODUCTION}

claims, more or less valid, exact and accepted, to assess and deal with the needs of people. Underlying the law and practice of their activities are principles of social policy which relate need on the one hand to supply and demand on the other.

In many ways welfare needs are engendered or intensified by the character of industrial organisation. Industrial development often entails long hours of work, insanitary working conditions, squalid domestic housing and poor amenities, all of which pose a threat to health which is met sooner or later by government action to compel minimum standards. Fluctuations in trade as well as changing methods of production lead to unemployment and redundancy, a threat to the incomes of workers which may be countered by some kind of income-maintenance programme or, generally at a later stage of development, by government intervention in the economy to maintain a given level of employment. At the same time, advances in scientific and technological knowledge lead to new industrial techniques and demands for educated and skilled workers. Thus the appropriate training for employment becomes an important need in industrial countries.

Developments in science and technology both change industrial processes and also affect other areas of knowledge. The combination of increased economic resources and increased scientific understanding opens up increased possibilities of tackling an ever wider range of social problems. Hence new needs for social intervention are created, for example in medicine, as it becomes possible to treat conditions earlier regarded as unchangeable. The peculiar needs created by industrialisation are, then, partly the result of hardships imposed by the economic system and partly the result, paradoxically, of the greater resources that can be devoted to investigating and remedying an increasing variety of social problems.

The need for public social-security and welfare arrangements is affected by family and social structure as well as by the form of industrial organisation. The type of family most commonly found in rich industrial countries is the nuclear group of parents and dependent children, a unit not always completely equipped to provide material security and support for its members in face of the hazards associated with an industrial economy. Finally, various aspects of social structure economic, political, social, racial and ethnic differences - may all have important implications for need or demand for public-security and welfare programmes.

In the second part of the book the three welfare models are used to analyse the British system, and especially to determine how far British arrangements are consistent with the values inherent in the socialist model. The analysis shows that in practice the distribution of goods and services in Britain is associated very tenuously with need; other factors 
such as class, family background, geography and professional interests are often more important in determining standards of living and opportunities.

There are various explanations for the failure to realise a distribution based on the idea of citizenship. Fundamental, perhaps, is a lack of political will or power. Both power and will can, however, be changed and the question therefore arises as to what kind of public policies would in fact be required to bring about a system where supply was closely related to need. This is the subject of the third part of the book, which discusses such crucial matters as the significance of selective and universal services, the question of democratic control and participation in policy-making and the importance of planning and research in relation to setting objectives, establishing priorities, measuring needs and assessing the quality of public provision. 